Anna BIAŁK-WOLF

Wyższa Szkoła Turystyki i Hotelarstwa w Gdańsku

\title{
OCENA SZANS ROZWOJU EKOTURYSTYKI NA TERENACH ZURBANIZOWANYCH
}

\section{Wstęp}

Na wstępie niniejszego opracowania należy uzasadnić, dlaczego warto przeanalizować zagadnienie dotyczące szans i zalet rozwoju ekoturystyki na terenach zurbanizowanych. Mimo że to tylko na pozór sprzeczne połączenie (WU, WANG, Ho 2010) pojawia się już od lat 90. XX w., stanowi nadal sporadycznie temat analiz naukowych. Warto podkreślić, że również w Polsce pojawiły się próby analizy ekoturystyki na terenach zurbanizowanych, do których niewątpliwie należy województwo śląskie (KACZMARSKA 2010). Niemniej zdecydowanie częściej zauważa się analizę ekoturystyki w połączeniu z agroturystyką, stanowiącą pewne "przeciwieństwo" dla turystyki na terenów zurbanizowanych.

Ekoturystyka kojarzona jest głównie $\mathrm{z}$ elementami środowiska naturalnego, a tereny zurbanizowane w dużej mierze mają ograniczony dostęp do tychże zasobów. Należy jednak zauważyć, że ekoturystyka jest również pewnym wyznacznikiem nastawienia do turystyki generalnie. Trend dotyczący "ekologizacji” nie ogranicza się tylko i wyłącznie do samych walorów naturalnych, ale również do podejścia do rozwoju turystyki. W związku z tym elementy „eko” mają uzasadnienie także na terenach zurbanizowanych, mogą być traktowane jako czynnik rozwoju regionalnego i przyczyniać się do podnoszenia konkurencyjności produktów turystycznych tam oferowanych. 


\section{Istota koncepcji ekoturystyki i jej krytyka}

Według najczęściej przytaczanej definicji Międzynarodowego Towarzystwa Ekoturystycznego, ekoturystyka to „świadoma podróż do naturalnych miejsc przyrodniczych, która z jednej strony pomaga chronić środowisko naturalne, a z drugiej podtrzymuje dobrobyt lokalnych mieszkańców" (OKECH 2009).

Ekoturystyka ma za zadanie ${ }^{1}$ :

- minimalizować wpływ na otoczenie terenów recepcyjnych;

- budować środowiskową i kulturową świadomość uczestników ruchu turystycznego;

- dostarczać pozytywnych doświadczeń zarówno turystom, jak i mieszkańcom;

- zapewniać bezpośrednie korzyści finansowe dla ochrony przyrody;

- zwiększać wrażliwość organizacji politycznych na ochronę środowiska i klimatu społecznego.

Unikając $w$ tym miejscu przedstawiania dalszych definicji ekoturystyki ${ }^{2}$ warto podkreślić, iż w wielu z nich wskazuje się także na takie elementy, jak: edukacja ekologiczna, zaangażowanie lokalnych społeczności, podróżowanie $w$ małych grupach, znaczenie lokalnej kultury, mała skala występowania, zyski finansowe dla lokalnej społeczności, możliwość spędzenia czasu $z$ rodziną (HIGHAM, LÜCK 2002, LU, STEPCHENKOVA 2012). R.E. KRIDER i in. (2010) twierdzą, że generalnie w definicjach ekoturystyki dominuje pięć obszarów odniesienia: środowisko naturalne, ochrona, kultura, korzyści dla lokalnej ludności i edukacja. D.B. WEAVER, L.J. LAWTON (2007) uważają z kolei, iż panuje konsensus co do tego, iż ekoturystyka powinna spełniać trzy kluczowe kryteria:

- atrakcje powinny bazować na walorach naturalnych;

- interakcje między odwiedzającymi a tymi atrakcjami powinny opierać się na nauce i edukacji;

- doznania i zarządzanie produktem powinny być zgodne z zasadami rozwoju zrównoważonego (zasadami ekologicznymi, społeczno-kulturowymi i ekonomicznymi).

Autorzy ci jednak podkreślają, iż każde z tych kryteriów pozostawia dużą swobodę interpretacji.

\footnotetext{
${ }^{1}$ http:/ / www.ecotourism.org/what-is-ecotourism; 21.09.2014; thum. A. Kaczmarska (2010).

2 Przegląd definicji można znaleźć w D. ZARĘBA (2006, s. 48-49). R.E. KRIDER i in. (2010) przytaczają pracę D. FENNELLA (2001), który zidentyfikował aż 85 definicji ekoturystyki.
} 
Zauważa się częste traktowanie ekoturystyki jako synonimu turystyki zrównoważonej, w przypadku której podkreśla się równorzędność racji ekonomicznych, społecznych i ekologicznych. Z drugiej strony ekoturystyka jest opisywana i ujmowana w literaturze jako rdzeń turystyki zrównoważonej i odbywa się najczęściej na terenach o wybitnych walorach przyrodniczych.

Wielu autorów podkreśla, że kluczowy element ekoturystyki stanowi edukacja i to właśnie ona jest czynnikiem odróżniającym ekoturystykę od innych form turystyki powiązanych ze środowiskiem naturalnym. Pojawia się przy tym spostrzeżenie, że określenie "turystyka związana z naturą" jest zbyt często zamiennie stosowane z pojęciem „ekoturystyka”, a sam element środowiska naturalnego nie gwarantuje jeszcze traktowania tam występującej turystyki jako zrównoważonej (OKECH 2009).

Analizując ekoturystykę warto jeszcze krytycznie spojrzeć na jej rozwój. Wydaje się, że niektóre jej cechy charakterystyczne ukazane w szerszym kontekście przestają mieć wymiar ekologiczny. Jako przykład można podać pojawiającą się cechę ekoturystyki dotyczącą podróżowania w małych grupach. Warto się jednak tutaj zastanowić nad tym, jak to oddziałuje na wybór środków transportu i ich wpływ na środowisko naturalne. Inna dyskusyjna kwestia dotyczy faktu odbywania podróży "do nieznanych zakątków”, które na ogół charakteryzują się tym, że znajdują się w znacznej odległości od miejsca zamieszkania turystów, co z kolei powoduje konieczność odbywania długich podróży, a te przyczyniają się do degradacji środowiska. „Indywidualizacja podróży" też powinna być w tym kontekście krytycznie rozpatrywana.

Innym dyskusyjnym zagadnieniem jest zauważalny "ekoszpan”, który przyczynia się do nadużywania tego pojęcia. J. HIGHAM, M. LÜCK (2002) wskazują ponadto na niemożliwość pogodzenia dwóch cech ekoturystyki, mianowicie naturalności środowiska oraz zadowalającego poziomu infrastruktury turystycznej. Kolejny krytyczny element dotyczy szacunków wielkości tego segmentu, gdyż występują duże różnice w jego ocenie, które wynikają po części z braku zgody co do definicji zarówno ekoturystyk (WEAVER 2001), jak i samej ekoturystyki (BUCKLEY 2013). Niemniej można przyjąć, że ekoturystyka zajmuje istotne miejsce na rynku turystycznym. Od $1990 \mathrm{r}$. funkcjonuje Międzynarodowe Towarzystwo Ekoturystyczne, które aktywnie promuje podróże zgodne $\mathrm{z}$ ideą ekoturystyki ${ }^{3}$, a od 2002 r. jest wydawane czasopismo naukowe poświęcone temu tematowi (,Journal of Ecotourism").

\footnotetext{
${ }^{3}$ http://www.ecotourism.org/ties-overview, oficjalna strona Międzynarodowego Towarzystwa Ekoturystycznego; 21.09.2014 r.
} 
Można przypuszczać, że ta forma turystyki będzie się nadal prężnie rozwijać, gdyż „ekologizacja” turystyki funkcjonuje w harmonii z innymi trendami obserwowanymi na rynku usług turystycznych, do których możemy zaliczyć: wzrost świadomości zdrowotnej społeczeństwa, podnoszący się poziom wykształcenia, wzrost znaczenia edukacyjnej funkcji turystyki, zwiększenie zainteresowania sztuką, kulturą, moda na miejsca nieznane czy indywidualizację, poszukiwanie autentyczności.

\section{Profil ekoturystów}

Z uwagi na fakt, iż w przypadku ekoturystyki kluczową rolę odgrywają sami turyści i ich wartości, zostaną oni w tym miejscu bliżej scharakteryzowani. Powszechnie przyjmuje się, iż dla tej grupy turystów najważniejszym czynnikiem wpływającym na decyzję o podjęciu podróży jest występowanie wybitnych walorów naturalnych. Badania jednakże wskazują, iż ekoturyści nie stanowią homogenicznej grupy konsumentów (KRIDER i in. 2010), co z kolei może stanowić kolejny argument na rzecz szans rozwoju ekoturystyki na terenach zurbanizowanych.

W grupie czynników satysfakcji ekoturystów analizuje się położenie destynacji, a wśród nich bliskość miast i atrakcji oraz dostępność komunikacyjną (LU, STEPCHENKOVA 2012). Czynniki te nie są wprawdzie krytyczne dla ekoturystów - jak wykazały badania W. LU i S. STEPCHENKOVEj (2012) - ale uważanie ich znaczenia jako „neutralne” wskazuje, iż ich obecność nie przekreśla szans na uprawianie ekoturystyki.

Zostały przeprowadzone próby identyfikacji wyróżników, na podstawie których można określić odwiedzających jako ekoturystów. Zawierają one trzy wymiary: motyw społeczny (edukacyjny), chęć odwiedzenia dzikich i nienaruszonych terenów, czasowe zaangażowanie. Trzeba jednak podkreślić, iż są one bardzo obszerne, co powoduje, że właściwie większość turystów można określić jako ekoturystów (OKECH 2009).

Często w literaturze przyjmuje się rozróżnienie dwóch skrajnych typów turystów, mianowicie „twardych” i „miękkich” (LU, STEPCHENKOVA 2012, WEAVER 2001). "Miękki” ekoturysta traktuje ekoturystykę jako element szerszego produktu turystycznego. Preferuje krótkie podróże w dużych grupach i zależy mu na komforcie podróżowania. Dla kontrastu, "twardy” ekoturysta kładzie nacisk na osobiste doznania podczas podróży, jest aktywny 
fizycznie i preferuje podróże specjalistyczne. Można przyjąć, iż niemal każdy turysta odnajdzie się na tym kontinuum.

W polskiej literaturze pojawia się podział na pięć typów konsumentów w zależności od poziomu świadomości ekologicznej. Typ „czarny” charakteryzuje osoby z brakiem wiedzy o ekologii i nieoszczędnym użytkowaniem zasobów. Typ "szary” to osoby o niskiej wiedzy ekologicznej, u których nawyk oszczędzania wynika tylko z pobudek ekonomicznych. W przypadku typu "szarozielonego" mamy do czynienia ze znaczną wiedzą ekologiczną turystów, ich zachowanie jest jednakże w dużej mierze podyktowane snobizmem. Typ „zielony” to turyści, którzy mają nie tylko duży zasób wiedzy ekologicznej, ale również wyróżniają się zachowaniem dążącym do ochrony środowiska. Typ ,jaskrawozielony” został wydzielony dla osób wpadających niejednokrotnie $\mathrm{w}$ skrajne pojmowanie ochrony środowiska, postulujące powrót do natury (ZAREMBA 1997).

Analiza literatury dotyczącej różnych typów turystów przeprowadzona przez W. LU i S. STEPCHENKOVĄ (2012) wskazuje, iż nie tylko elementy związane bezpośrednio ze środowiskiem naturalnym są dla nich istotne. Znaczenie mają również zasoby kulturowe oraz możliwość spędzania czasu z rodziną.

Można przyjąć, iż turyści ekologiczni różnią się od pozostałych nastawieniem do turystyki, którą postrzegają nie tylko jako rozrywkę, ale również metodę wzbogacania swojej osobowości i są świadomi jej skutków (zarówno negatywnych, jak i pozytywnych) dla obszarów recepcji turystycznej. Wykazują jednakże zróżnicowane potrzeby i nie ma przesłanek do twierdzenia, iż tereny zurbanizowane nie są celem ich wypraw.

\section{Ekoturystyka na terenach zurbanizowanych jako innowacyjny produkt turystyczny}

Jak wykazano w pierwszej części niniejszej pracy, definicje ekoturystyki oferują najczęściej kombinację ochrony ekologicznej i kulturowej oraz podniesienie lokalnej świadomości w zakresie ochrony tychże walorów. Inne elementy definicji, takie jak: społeczność lokalna, dziedzictwo kulturowe, edukacja - odnoszą się przynajmniej $\mathrm{w}$ takim samym stopniu (jeśli nie w większym) do zjawiska turystyki na terenach zurbanizowanych ${ }^{4}$.

\footnotetext{
${ }^{4}$ Niemniej identyfikowane są również definicje ekoturystyki wykluczające jej pojawienie się na terenach zurbanizowanych, stanowią one jednakże rzadkość (por. ZOBRE 2013).
} 
Koncepcja ekoturystyki na terenach zurbanizowanych opiera się na spojrzeniu przez pryzmat miasta jako destynacji turystycznej (OKECH 2009) i została zapoczątkowana przez organizację turystyczną w Toronto. Ukazuje to, jak miasto może promować siebie, indywidualny biznes i atrakcje, dostarczając jednocześnie turystom unikatowych doświadczeń i generować zapotrzebowanie na rozwój zrównoważony. Za pierwszą definicję tego pojęcia uznaje się zaproponowaną przez „Blackstone Corporation” w 1996 r., według której oznacza ona „sposób zrównoważonego podróżowania na tereny zurbanizowane" (FRESLON 2010). Koncepcja ekoturystyki na terenach zurbanizowanych została rozwinięta podczas konferencji poświęconej tej tematyce w 2004 r., kiedy doszło do konsensusu uznającego, iż ,jest ona szansą na ochronę biologicznej i społecznej różnorodności, tworzenie nowych miejsc pracy oraz podniesienie jakości życia" w środowisku zurbanizowanym, i zmierza do osiągnięcia następujących celów ${ }^{5}$ :

- przywrócenie i ochrona walorów naturalnych i kulturowych zawierających naturalne krajobrazy oraz lokalną kulturę;

- maksymalizowanie korzyści i zaangażowania lokalnych społeczności jako właścicieli, inwestorów, gospodarzy i przewodników;

- edukacja odwiedzających i rezydentów w kwestii środowiska naturalnego, dziedzictwa zasobów oraz rozwoju zrównoważonego;

- redukcja naszego wpływu na środowisko.

W trakcie omawianej konferencji przyjęto następującą definicję ekoturystyki na terenach zurbanizowanych: "podróż do naturalnego środowiska znajdującego się w otoczeniu miejskim". Według innej definicji zjawisko to oznacza: "formę turystyki, która respektuje naturalny ekosystem miasta" (LU, STEPCHENKOVA 2012, s. 703). Członkowie Stowarzyszenia Turystyki Zielonej twierdzą, że "turystyka zielona na terenach zurbanizowanych jest synonimem ekoturystyki i oznacza podróżowanie i odkrywanie miast i terenów wokół niego, dowartościowujące zasoby kulturowe i naturalne przez odwiedzających oraz mieszkańców" (LU, STEPCHENKOVA 2012).

Cechy charakterystyczne ekoturystyki na terenach zurbanizowanych zawierają (DODDS, JOPPE 2001):

- odpowiedzialność za środowisko - ochrona i wspieranie środowiska naturalnego w celu zagwarantowania długotrwałego zdrowego ekosystemu;

5 Urban Ecotourism Declaration, 2004, http://www.planeta.com/ecotravel/ tour/urban declaration.html; 28.09.2014 r. 
- witalność lokalnej gospodarki - wspieranie lokalnej gospodarki, biznesu i społeczności, aby zagwarantować witalność gospodarki i rozwój zrównoważony;

- wrażliwość kulturową - respektowanie i docenianie kultury i różnorodności kulturowej, aby zagwarantować funkcjonowanie lokalnej kultury;

- bogactwo doświadczeń - dostarczanie wzbogacających i satysfakcjonujących doświadczeń poprzez aktywny, osobisty udział i zaangażowanie w naturę, życie mieszkańców, miejsce i kulturę.

Ekoturystyka na terenach zurbanizowanych może być ponadto traktowana jako odpowiedź na dysfunkcyjność turystyki, rozumianej jako negatywne skutki jej rozwoju. Paradoksalnie, rozwój urbanizacji prowadzi do wzrostu wykształcenia i świadomości ekologicznej, a ta z kolei do zwiększenia znaczenia walki z negatywnymi skutkami tego rozwoju. Do pozytywnych czynników umożliwiających rozwój ekoturystyki na terenach zurbanizowanych można zaliczyć fakt, iż mieszkańcy miast są lepiej wykształceni i bardziej świadomi znaczenia środowiska naturalnego dla jakości życia. Badania H. ZHANG, S. LEI (2012) dowodzą, iż wiedza mieszkańców danego terenu o środowisku naturalnym pozytywnie wpływa na stosunek do rozwoju ekoturystyki na tym obszarze.

Należy także zauważyć, że jeżeli przeciwstawimy koncepcję „natury” pojęciu „kultura” (rozumianej jako wytwór człowieka, a więc „nienaturalnej"), to rzeczywiście można wyciągnąć wniosek, iż ekoturystyka (naturalna) jest niemożliwa do implementacji na terenach zurbanizowanych. Jednakże jest to sprawa natury filozoficznej, bo można uznać, iż człowiek wraz ze swoją działalnością jest częścią natury. Badania preferencji turystów pokazują, iż nie oczekują oni tylko "nienaruszonej natury”, ale są również zainteresowani terenami zmodyfikowanymi przez człowieka, o ile są estetyczne i dają możliwość podziwiania dzikiego życia (HIGHAM, LÜCK 2002). Można więc przyjąć, iż tereny naturalne nie oznaczają automatycznie terenów pozbawionych ludzi, oraz że „natura” funkcjonuje także w miastach. Ekoturystyka jest obserwowalna na terenach oferujaccych pewne naturalne tereny, które jednakże zostały zmodyfikowane poprzez działalność człowieka. Co więcej, większość definicji ekoturystyki mówi o „bazowaniu na środowisku naturalnym", co nie oznacza, że musi być ono niezamieszkałe albo pozostawione $\mathrm{w}$ nienaruszonym stanie.

Analizując idealną koncepcję podróży ekoturystycznej przedstawioną przez Zarębę (2006) nie zidentyfikowano żadnego aspektu, który mógłby 
być sprzeczny z ideą uprawiania tego rodzaju turystyki na terenach zurbanizowanych. Co więcej, rozwój aglomeracji jest w dużej mierze uwarunkowany aspektami pozaekonomicznymi, do których należy niewątpliwie stan środowiska naturalnego. Tereny posiadające dużo walorów naturalnych stają się także atrakcyjnym miejscem zamieszkania, co z kolei może przyczynić się do wzrostu zainteresowania inwestorów i klasy kreatywnej, która stanowi bezpośredni impuls do rozwoju regionów (FLORIDA 2007). Także szereg studiów przypadków analizowanych w literaturze wskazuje na szerokie możliwości rozwoju ekoturystyki na terenach zurbanizowanych (OKECH 2009, HIGHAM, LÜCK 2002). Ponadto na znaczeniu zyskują produkty powiązane ze środowiskiem naturalnym (JAAFAR, MAIDEEN 2012).

Proekologiczny kierunek rozwoju turystyki stał się dominującym trendem, co powoduje konieczność uwzględnienia go nie tylko w turystyce na obszarach posiadających wyjątkowe walory naturalne, ale także na terenach zurbanizowanych. Ekoturystyka może przyczyniać się do podniesienia atrakcyjności miast, nie tylko dla turystów, ale także dla mieszkańców. Wydaje się, iż nie sam charakter destynacji, ale sposób, w jaki jest ona zarządzana, wartości, które stanowią bazę tego zarządzania, a także z drugiej strony priorytety, motywacje i wartości osób tam się udających powinny pozwalać na funkcjonowanie i rozwój ekoturystyki. Można więc uznać, iż większość definicji ekoturystyki nie wyklucza jej rozwoju na terenach zurbanizowanych, a motywacje turystów mogą przyczynić się do ekologizacji turystyki na terenach zurbanizowanych, przyczyniając się do kreowania innowacyjnego ${ }^{6}$ produktu turystycznego i trendu XXI w. Należy więc stwierdzić, iż tereny zurbanizowane mają potencjał do rozwoju ekoturystyki, a wiąże się to z licznymi pozytywnymi zjawiskami.

J. Higham i M. Lück (2002) wskazują na następujące zalety rozwoju ekoturystyki w miastach:

- umożliwia korzystanie z już istniejącej infrastruktury i transportu, dzięki czemu nie ma potrzeby degradowania środowiska naturalnego oraz inwestowanie w nowe obiekty;

- umożliwia przywrócenie naturalnych obszarów poprzez ochronę zagrożonych i odtworzenie populacji rzadkich gatunków występujących na danym terenie;

${ }^{6}$ Zgodnie z koncepcją Schumpetera zakładająca, iż innowacją określamy nową kombinację istniejących elementów, można uznać, że w przypadku ekoturystyki na terenach zurbanizowanych właśnie z takim zjawiskiem mamy do czynienia i stanowi ona produkt innowacyjny (por. CAMISÓN, MONFORT-MIR 2012). 
- stwarza możliwość edukacji szerokich rzeszy ludzi (Okech 2009);

- stanowi szansę ożywienia gospodarczego, przy czym podkreśla się, że nie jest zbytnio narażona na sezonowość.

Należy zwrócić uwagę na fakt, iż ekoturystyka na terenach zurbanizowanych może być postrzegana jako innowacyjny produkt turystyczny, gdyż zaspokaja potrzeby w nowoczesny sposób, łącząc w sobie z pozoru przeciwstawne idee. Co więcej, w obecnych czasach obserwujemy pewną „modę" na bycie ekologicznym, a więc czynnik „eko” w miastach może przyczynić się do zwiększenia ich konkurencyjności. W szerszym aspekcie może też uwrażliwić mieszkańców miast na zagadnienia związane z ekologią.

Podsumowując należy uznać, iż implementowanie praktyk ekoturystycznych na terenach zurbanizowanych może z jednej strony przyczynić się do zwiększenia wpływów z turystyki w miastach $\mathrm{z}$ uwagi na swoją konkurencyjność, $\mathrm{z}$ drugiej zaś strony $\mathrm{w}$ długim czasie może przyczynić się do poprawy jakości życia w miastach poprzez zwiększenie świadomości ekologicznej jej mieszkańców. Stanowi też element, który może być wykorzystany w marketingu miejsc, gdyż wpisuje się w obecne trendy.

\section{Zakończenie}

Ekoturystyka stanowi nie tylko określoną formę turystyki, ale jest także wyrazem potrzeb społecznych dotyczących świadomego podróżowania w zgodzie z zasadami zrównoważonego rozwoju. Trend ten obserwujemy $\mathrm{w}$ wielu dziedzinach naszego życia, a wynika on $\mathrm{z}$ większej świadomości ekologicznej, wyższego poziomu wiedzy i łatwiejszego do niej dostępu, a także z coraz dotkliwiej obserwowanych negatywnych skutków rabunkowej gospodarki wobec środowiska naturalnego. W pewnym stopniu jest on też wynikiem mody. Tak więc regiony turystyczne $\mathrm{w}$ celu zwiększenia swojej konkurencyjności powinny mieć na uwadze ekoturystykę jako element odnoszący się generalnie do rozwoju turystyki na danym terenie, a nie wyłącznie do terenów o wybitnych walorach naturalnych.

Ekoturystyka została tu ukazana jako pewien sposób myślenia o turystyce, a nie tylko jako wąsko pojmowana forma turystyki, co z kolei uwidacznia szanse jej rozwoju na terenach zurbanizowanych. Może ona stanowić także ważny element uzupełniający istniejących produktów turystycznych w miastach. 


\section{Bibliografia}

BUCKLEY R., 2013, Defining ecotourism: consensus on core, disagreement on detail, [w:] International Handbook on Ecotourism, R. Ballantyne, J. Packer, E. Ekgar Publishing Limited, UK, s. 9-14.

CAMISÓN C., MONFORT-MIR V.M., 2012, Measuring innovation in tourism from the Schumpeterian and the dynamic-capabilities perspectives, „Tourism Management”, 33, s. 776-789.

DODDS R., JOPPE M., 2001, Promoting Urban Green Tourism: The development of the Other Map of Toronto, "Journal of Vacation Marketing", 7, 3, s. 261-267.

FENNELL D., 2001, A content analysis of ecotourism definitions, "Current Issues in Tourism”, 4, s. 403-421.

FLORIDA R., 2007, The flight of the creative class. The new global competition for talent, Harper Collins, NY.

FRESLON L., 2010, Urban Ecotourism - The Case of Lac de Maine Leisure Park, http://ecoclub. com/articles/305-urban-ecotourism-lac-de-maine; 21.09.2014 r.

Higham J., LÜCK M., 2002, Urban Ecotourism: A Contradiction in Terms?, „Journal of Ecotourism”, 1, 1, s. 36-51.

http:/ / www.ecotourism.org/what-is-ecotourism; 21.09.2014; tłum. A. Kaczmarska (2010).

JAAFAR M., MAIDEEN S.A., 2012, Ecotourism-related products and activities, and the economic sustainability of small and medium island chalets, „Tourism Management", 33, s. 683-691.

KACZMARSKA A., 2010, Możliwości rozwoju agro- $i$ ekoturystyki w Polsce na przykładzie województwa śląskiego, "Oeconomia”, 9 (4), s. 211-223.

Krider R.E., ARGUello A., CAMPBell C., FraSer S., Mora J.D., 2010, Trait and Image Interaction in Ecotourism Preference, "Annals of Tourism Research", 37, 3, s. 779-801.

LU W., STEPCHENKOVA S., 2012, Ecotourism experiences reported online: Classification of satisfaction attributes, „Tourism Management”, 33, s. 702-712.

OKECH R.N., 2009, Developing urban ecotourism in Kenyan cities: A sustainable approach, "Journal of Ecology and Natural Environment", 1, 1, s. 1-6.

WEAVER D.B., 2001, Ecotourism as Mass Tourism: Contradiction or Reality, "Cornell Hotel and Restaurant Administration Quarterly", 42, s. 104-112.

WEAVER D.B., LAWTON L.J., 2007, Twenty years on: The state of contemporary ecotourism research, „Tourism Management", 28, 5, s. 1168-1179.

WU Y.Y., WANG H.L., HO Y. F., 2010, Urban ecotourism: Defining and assessing dimensions using fuzzy number construction, „Tourism Management”, 31, s. 739-743.

www.ecotourism.org/ties-overview; 21.09.2014 r.

www.planeta.com/ecotravel/tour/urbandeclaration.html; 28.09.2014 r.

ZARĘBA D., 2006, Ekoturystyka, PWN, Warszawa.

ZAREMBA S., 1997, Ekologia produktów a idee zielonego konsumeryzmu, w: Ekologia wyrobów, Materiały konferencyjne, Akademia Ekonomiczna w Krakowie, Katedra Technologii i Ekologii Wyrobów, Polskie Towarzystwo Towaroznawcze - Zarząd Główny, Kraków.

ZOBRE K., 2013, Greening Urban Tourism: Progress in Urban Ecotourism, http://www.aidemocracy. $\mathrm{org} /$ students/ world-insight-essay-series-greening-urban-tourism-progress-in-urban-eco tourism; 21.09.2014 r.

ZHANG H., LEI S.L., 2012, A structural model of residents' intention to participate in ecotourism: The case of a wetland community, „Tourism Management", 33, s. 916-925. 